\title{
Sectoral regularities of productivity growth in developing countries - A Kaldorian interpretation
}

Citation for published version (APA):

Pieper, U. E. (2000). Sectoral regularities of productivity growth in developing countries - A Kaldorian interpretation. MERIT, Maastricht Economic Research Institute on Innovation and Technology. MERIT Research Memoranda No. 030 https://doi.org/10.26481/umamer.2000030

Document status and date:

Published: 01/01/2000

DOI:

10.26481/umamer.2000030

Document Version:

Publisher's PDF, also known as Version of record

\section{Please check the document version of this publication:}

- A submitted manuscript is the version of the article upon submission and before peer-review. There can be important differences between the submitted version and the official published version of record.

People interested in the research are advised to contact the author for the final version of the publication, or visit the DOI to the publisher's website.

- The final author version and the galley proof are versions of the publication after peer review.

- The final published version features the final layout of the paper including the volume, issue and page numbers.

Link to publication

\footnotetext{
General rights rights.

- You may freely distribute the URL identifying the publication in the public portal. please follow below link for the End User Agreement:

www.umlib.nl/taverne-license

Take down policy

If you believe that this document breaches copyright please contact us at:

repository@maastrichtuniversity.nl

providing details and we will investigate your claim.
}

Copyright and moral rights for the publications made accessible in the public portal are retained by the authors and/or other copyright owners and it is a condition of accessing publications that users recognise and abide by the legal requirements associated with these

- Users may download and print one copy of any publication from the public portal for the purpose of private study or research.

- You may not further distribute the material or use it for any profit-making activity or commercial gain

If the publication is distributed under the terms of Article $25 \mathrm{fa}$ of the Dutch Copyright Act, indicated by the "Taverne" license above, 
Sectoral regularities of productivity growth in developing countries - A Kaldorian interpretation

Ute Pieper

2/20-031

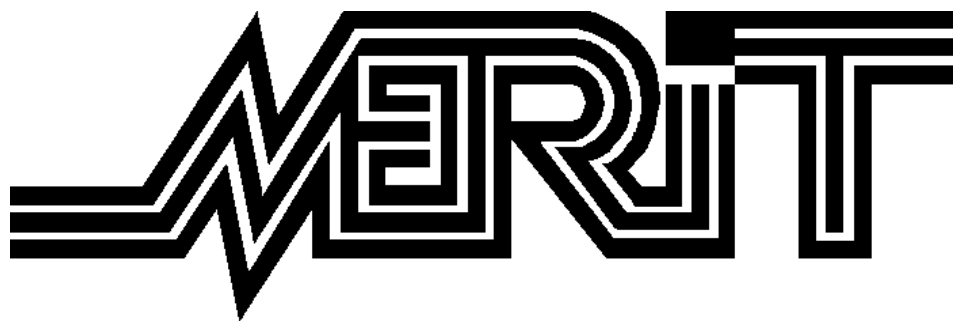

Maastricht Economic Research Institute on Innovation and Technology

MERIT - P.O. Box 616 - 6200 MD Maastricht

The Netherlands

Tel. --31-43-3883875 - Fax. --31-43-3884905 
Sectoral regularities of productivity growth in developing countries --

\title{
A Kaldorian interpretation
}

\section{Ute Pieper*}

Forthcoming in Cambridge Journal of Economics

(First draft: October 1999, Second draft: November 2000, This version: August 2001)

Keywords: increasing returns, sector-specific productivity growth, Kaldor-Verdoorn Law, nonlinear statistical modeling

JEL: O14, O11, O30, O40

\begin{abstract}
$\underline{\text { Abstract }}$
This paper provides a Kaldorian interpretation for empirical regularities of productivity growth at the sectoral level of the economy. The statistical evidence is based on a data set drawn from internationally compatible time series for employment and value added in thirty developing countries. Based on novel nonlinear statistical techniques the findings show: (i) a regular pattern of positive sectoral employment elasticities with respect to output growth, (ii) robust differences across sectors in the magnitude of the employment elasticities, and (iii) employment elasticities for all sectors that are significantly less than unity suggesting strong evidence for increasing returns at the sector level of the economy.
\end{abstract}

*MERIT, Economics Department, Maastricht University

Email: ute.pieper@merit.unimaas.n 


\section{ACKNOWLEDGEMENTS}

I wish to thank conference participants in particular Bart van Ark, Stephen Broadberry and Albrecht Ritschl for stimulating discussions at the EHES workshop on Structural Change and Economic Growth in Historical Perspective in Lund, Sweden from August 29 to September 2, 1999. Comments by Eugene Canjels, Sergio Destefanis, Duncan Foley, David Kucera, Tom Michl, Will Milberg, Jaime Ros, Lance Taylor and two anonymous referees are gratefully acknowledged. Remaining errors are my own. My special thanks to Diana Alarcon, Christine Enzler and Rolph van der Hoeven of the ILO for their efforts in providing sectoral employment series. This research was supported by the Center for Economic Policy Analysis, New School University and by a Marie Curie Fellowship of the European Commission

programme Improving the Human Research Potential and the Socio-Economic Knowledge Base under contract no. HPMF-CT-1999-00204. 


\section{Introduction}

One of the most important phenomena of the postwar economic performance of nations has been the substantial and persistent difference between countries' rates of growth of productivity and output. Moreover, some economies have achieved sustained growth in productivity, while others have shown little or no improvement resulting in substantial differences in levels of income per capita or income per worker across countries. Despite increasing efforts over the past decade and a half into the inquiry of the reasons, our understanding of the underlying processes is still very limited, and they remain a source of controversy. Most of the empirical and theoretical work on growth has focused on aggregate output and productivity and is concerned primarily with the question of whether countries converge to a common long-run growth path. There are two important issues relevant for the present analysis. First, recent work has pointed out the limited success of neoclassical theory in modeling experienced economic growth both in cross-section and time-series data (Durlauf and Quah, 1999; Temple, 1999). It has been argued that the socalled "puzzle" may be the result of the high level of aggregation of the variables - mostly macroeconomic — under investigation (e.g. Nelson, 1998).

Second, despite dramatically growing openness of both goods and capital markets, there is now compelling evidence that in addition to country-specific regularities there are substantial industry or sector-specific determinants of aggregate productivity. For example, Bernard and Jones (1996) examined patterns of catch-up across sectors for fourteen countries during the 1970s and 1980s and found substantial evidence for diverging productivity levels in manufacturing industries contrary to the predictions of standard neoclassical growth models. $\square_{\text {In }}$ light of these recent findings this study addresses the question whether productivity growth is generated endogenously at the sector level of the economy.

The starting point of the analysis is the Verdoorn Law, which, in its simplest form, states that there is a close positive relationship between the long run rate of growth of manufacturing 
productivity and the long run rate of growth of manufacturing output. Although mostly discussed and applied in terms of the differences in productivity growth of advanced countries, the law has also been recognized as having a wider significance for the more general process of economic growth and development (Kaldor, 1978; Thirlwall and Dixon, 1975; Chenery et al., 1986). For the analysis of developing countries where labor surplus and capital scarcity are prevalent, it will be argued that a Kaldorian interpretation provides a consistent framework for the analysis of productivity growth.

In suggesting that a substantial part of productivity growth is endogenous to economic growth, Kaldor $(1966,1978)$ emphasized the theoretical significance of economies of scale for the development process. Similar to the arguments in the writings of development economists such as Young (1928) and Rosenstein-Rodan (1943), successful development requires the overcoming of inhibiting factors, including the presence of externalities and some form of increasing returns to scale.

The criticisms of Verdoorn's Law have been largely directed at Kaldor's interpretation and at the robustness of the empirical findings, especially the constancy of the Verdoorn ratio across countries in cross-sectional studies. ${ }^{2}$ This paper will address these two queries in the context of developing countries. In particular, the question regarding statistical robustness of estimates of the Verdoorn coefficient is dealt with on two levels. First, in addition to parametric robustness tests novel nonlinear statistical procedures are used in the detection of data regularities. In fact, the type of data smoothing techniques applied here can be a reliable tool in the detection of heterogeneity problems in the data. Second, the statistical evidence is based on a unique historical panel data set of thirty developing countries including sub-Saharan Africa, Latin America and South and East Asia for the period from the mid-1970s to the early 1990s. The data set is drawn from internationally compatible time series of employment and value 
added at the one-digit level of the International Standard Industry Classification (ISIC) codes, i.e., it covers nine main activities of the economy.

In almost all investigations, the Verdoorn Law is specified under the very restrictive assumption of a constant-parameter relationship between productivity growth and output growth. This is true for theoretical models of a technical progress function as well as the traditional aggregate production function. However, there is no theoretical or empirical reason that compels us to assume from the outset a linear functional form of the relation between the long run rate of growth of productivity and output growth. In particular, a constant-parameter function presumes that it can adequately represent the production relation of all units under investigation. Hence, new nonparametric techniques for data smoothing were utilized in this study in order to relax the constraints that assumed linearity imposes unnecessarily on the empirical estimates of the Verdoorn Law.

The findings from the statistical analysis show robust patterns for all sectors under investigation suggesting strong evidence for the prevalence of increasing returns when moving from the well-studied context of industrialized countries to developing economies. In particular, they suggest a regular nonlinear pattern of positive sectoral employment elasticities with respect to output growth across all nine sectors.

The remainder of the paper is divided as follows. Section 2 presents a Kaldorian interpretation for sectoral data regularities of productivity growth and derives the original model specification of Verdoorn's Law. Section 3 describes the data methodology and statistical evidence of the Kaldor-Verdoorn relationship for the nine main sectors included in the study. Then findings regarding the robustness of differences between patterns of productivity growth across sectors are presented. Section 4 presents results from local regression procedures that were used in the detection of nonlinear data regularities in labor productivity growth across sectors. Section 5 concludes and discusses directions for future research. 


\section{Kaldor's growth laws and the linear Verdoorn model}

\subsection{A Kaldorian interpretation}

In an attempt to explain differences among the rates of economic growth of industrialized countries, and in particular the comparatively poor postwar performance of the U.K., Kaldor (1966) proposed a set of fundamental relationships or stylized facts which later came to be known as Kaldor's Laws. Kaldor examined the Verdoorn relation using cross-country data at the sectoral level for twelve advanced countries over the early postwar period from the mid-1950

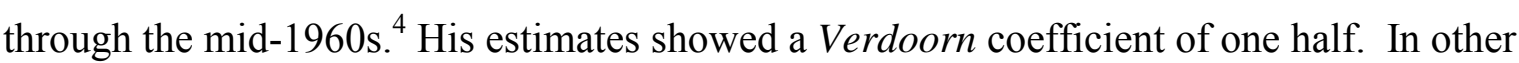
words, a one percent increase in output requires a 0.5 percent increase in labor and is associated with a 0.5 percent increase in the rate of growth of productivity.

While Verdoorn himself suggested that industrial production is subject to increasing

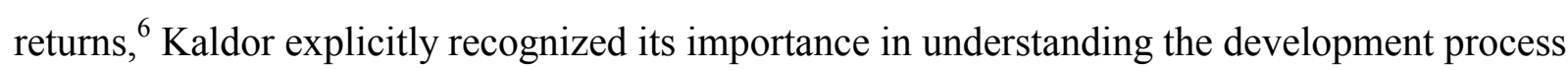
and it represents a core relationship in his theoretical model of cumulative growth. He modeled Verdoorn's Law theoretically on the idea of learning-by-doing, which formalizes the relationship between productivity and cumulative investment or production. Kaldor (1966, pp. 106-7) wrote:

"Learning is the product of experience-which means, as Arrow has shown (1962), that productivity tends to grow the faster, the faster output expands; it also means that the level of productivity is a function of cumulative output (from the beginning) rather than of the rate of production per unit of time. Second, as Allyn Young (1928) emphasized, increasing returns is a 'macro-phenomenon.' [..] At any one time, there are industries in which economies of scale may have ceased to be important. They may nevertheless benefit from a general industrial expansion which, as Young said, should be 'seen as an interrelated whole.' [... This in my view, is the basic reason for the empirical relationship between the growth of productivity and the growth of production which has come to be known as the 'Verdoorn Law' in recognition of P. J. Verdoorn's earlier investigations published in 1949. It is a dynamic rather than a static relationship - between the rates of change of productivity and of output, rather than between the level of productivity and the scale of output - primarily because technological progress enters into it, and is not just a reflection of economies of large-scale production" (emphasis in the original). 
At this point Kaldor's interpretation departs from Verdoorn's in order to explain growth

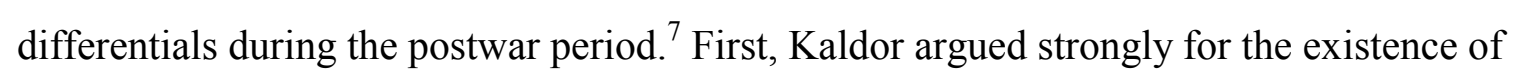
country-specific determinants of productivity growth. If productivity is the result of exogenous technical change, why are there widely varying productivity growth rates in the same industry in different countries? This fact according to Kaldor is evidence that the macroeconomic environment, the level and growth of demand, decisively influences the potential of productivity to increase in an economy (Michl, 1985). In other words, the potential for economies of scale may be enhanced or impaired depending on the macroeconomic conditions specific to countries.

Second, Kaldor also stressed the fact that even countries that are "mature" or industrialized remain dual economies subject to underemployment or "disguised unemployment" outside of the secondary sector even when surplus labor was depleted in the primary sectors (Kaldor, 1968, 1975). He argued: "It is the existence of an elastic supply curve of labor to the secondary and tertiary sectors which is the main pre-condition of a fast rate of development" (p. 120).

The latter point is of course of particular importance for the interpretation of the Verdoorn relation in the context of developing countries, which are the main focus of this empirical analysis. With no (or limited) exogenous technological change and a factor ratio that is assumed constant in the short run, output per worker changes only as a result of the presence of increasing returns. $\mathrm{q}$ It is under these conditions that the Verdoorn relation can be interpreted as reflecting exclusively the extent of increasing returns to scale (Ros, 2000). The presence of increasing returns to scale and labor surplus in Kaldor's interpretation allows this framework to depart from the standard neoclassical growth model.

In response to neoclassical criticism of this interpretation of the Verdoorn relation, Kaldor wrote: "Even if industrial output obeyed the law of constant returns, it could still be true that the growth of industrial output was the governing factor in the overall rate of economic 
growth (both in terms of total output and output per head) so long as the growth of industrial output represented a net addition to the effective use of resources and not just a transfer of resources from one use to another. This would be the case if (a) the capital required for industrial production was (largely or wholly) self-generated - the accumulation was an aspect, or a byproduct, of the growth of output; and (b) the labor engaged in industry had no true opportunitycost outside industry, on account of the prevalence of disguised unemployment both in agriculture and services. [..] The important implication of these assumptions is that economic growth is demand-induced, and not resource-constrained" (Kaldor, 1975, pp. 894-5).

\subsection{A basic model and Kaldor's specification of Verdoorn's Law}

Verdoorn's Law - as mentioned above — suggests the existence of a constant long-run relation between the growth of labor productivity and the rate of growth of industrial output. A simple production relation is given by

$$
\mathrm{Q} \equiv(\mathrm{Q} / \mathrm{E}) \mathrm{E}
$$

where $\mathrm{Q}$ is output, $\mathrm{E}$ is employment and $\mathrm{P}$ (equal to $\mathrm{Q} / \mathrm{E}$ ) is productivity. and taking logs, we get

$$
\mathrm{d} \log (\mathrm{Q}) \equiv \mathrm{d} \log (\mathrm{P})+\mathrm{d} \log (\mathrm{E}) \rightarrow \mathrm{q} \equiv \mathrm{p}+\mathrm{e}
$$

Rearranging gives:

$$
\mathrm{p} \equiv \mathrm{q}-\mathrm{e}
$$


Equation (iii) is an identity stating that the rate of growth of productivity (p) is equal to the difference between the rate of output growth (q) and the rate of growth of employment (e). Kaldor (1966) specified the Verdoorn relation in terms of a linear regression model:

$\mathrm{p}=\alpha_{\mathrm{K} 1}+\beta_{\mathrm{K} 1 \mathrm{q}} \quad$ with $\beta_{\mathrm{K} 1}>0$

or

$\mathrm{e}=-\alpha_{\mathrm{K} 2}+\beta_{\mathrm{K} 2} \mathrm{q}, \quad$ with $0<\beta_{\mathrm{K} 2}<1$

where $\alpha_{\mathrm{K} 1}=-\alpha_{\mathrm{K} 2}$ and $\beta_{\mathrm{K} 1}=\left(1-\beta_{\mathrm{K} 2}\right)$.

Several important issues regarding the specification and its interpretation arise. ${ }^{0}$ First, Kaldor regarded reduced-form model (2) to be preferred to (1) because the correlation between $\mathrm{p}$ and q could be partially spurious. He writes: "Clearly, since by definition $p=q-e$ in any situation in which e is either zero or constant there must be a perfect correlation between $\mathrm{p}$ and $\mathrm{q}$ but one which does not assert anything, since it is the automatic consequence of measuring the same thing twice over" (Kaldor, 1975, p. 892, emphasis in the original).

Second, for the presence of static or dynamic economies of scale in industry, Kaldor (1975) concludes that a "sufficient condition is the existence of a statistically significant relationship between e and q, with a regression coefficient which is significantly less than unity" (p. 893; emphasis in the original).

Third, in light of Kaldor's earlier statement regarding the independence of the labor supply, Rowthorn (1975A) offered an alternative formulation using employment growth as the regressor on productivity growth, with a positive correlation coefficient $\left(\beta_{R}>0\right)$ as evidence for 


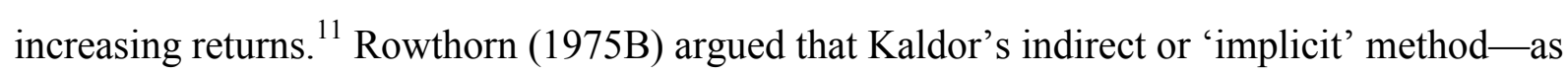
specified in equations 1 and 2-of estimating the relationships between $\mathrm{p}$, e, and $\mathrm{q}$ is only appropriate, when (i) “there is an 'unlimited' supply of labour.., and (ii) demand is not significantly affected by the movement of productivity or employment. Under these conditions it is formally correct to take $\mathrm{q}$ as the independent variable and to interpret the results as evidence about technology" (p. 900). In other words, under Kaldorian conditions as described in section 2, a positive association between the rate of growth of employment and the rate of growth of productivity (i.e. Rowthorn's reformulation) is equivalent to Kaldor's emphasis on a Verdoorn coefficient that is positive and significantly less than unity. In fact, the inverse regression of the Verdoorn Law would give the same result if the association measured is exact or a close fit.

However, the same way Kaldor's equation (1) may be partially spurious, this reformulation may be subject to the same problem. Due to the complication introduced by the productivity identity, equation (2) represents the "cleanest" form of the law for the investigation of the existence of increasing returns at the sectoral level of the economy. 2

Rowthorn (1975B) pointed out an additional problem regarding the simultaneity of the variables defined by the productivity identity. For instance, Kaldor's own interpretation of the Verdoorn relationship was in terms of a cumulative growth model. The identification problem in equation (2) results in the regressor output growth $(q)$ to be positively correlated with the disturbance term. However, the positive bias implies that a least-squares estimator of the employment elasticity is biased upward or against increasing returns to scale. Thus, in the case of equation (2) rejecting the null hypothesis of constant returns to scale will be more difficult due to the identification problem. The next section presents least-squares estimates for the Verdoorn relation as specified in equation (2) above followed by estimates based on nonparametric estimation techniques. 


\section{Estimates of the Verdoorn Law}

\subsection{Data methodology}

The sectoral evidence applied in this investigation consists of a set of internationally compatible panel data drawn from historical time series of employment and value added at the one-digit level of International Standard Industry Classification (ISIC) codes. The two main sources are: (i) the U.N. National Accounts for sectoral value added series, and (ii) the Yearbook of Labour Statistics by the International Labour Office (ILO) for sectoral employment series. $\frac{3}{\text { Since the }}$ 1970s the U.N. system of statistics has devised detailed survey guidelines for its collection of national data to ensure consistency for international comparison. This is why the two sets of sectoral data series can be considered to be consistent over time and space. Most importantly for the investigations at hand, however, the two sets of employment and output series are compatible with respect to the sector breakdown according to ISIC codes.

Additionally, a considerable effort was spent in particular on the raw series of the ILO to work on consistency of the sectoral employment data. The majority of the data is from national household or establishment surveys, and was further classified according to its quality based on criteria like for example changing definitions, discrepancies between figures for aggregate employment and the sum of sectoral employment, and obvious measurement errors. Then only country series of medium or high data quality were selected for inclusion in the study. Ultimately it was the sectoral employment series due to overall availability and exclusion based on poor quality that limited the size of the sample to 30 countries (while consistent value added series at the sector level are more widely available). Nevertheless, it should be pointed out that it probably represents the best time-series data available for developing country employment at this point in time due to its unique sector disaggregation which covers the entire economy. 
The observations of both employment and value added series are broken down into nine main activities or sectors for thirty developing countries from sub-Saharan Africa, Latin America and South and East Asia for the period between the mid-1970s and the early 1990s. The nine main sectors include: (1) agriculture, (2) mining and quarrying, (3) manufacturing, (4) public utilities, (5) construction, (6) wholesale and retail trade and hotel and restaurants (henceforth "commerce"), (7) transport and communication, (8) finance, insurance and real estate ("FIRE"), and (9) social services.

\subsection{Linear estimations and robustness of results}

The following is a first approximation of determining the employment elasticity with respect to sectoral output growth through least-squares regression:

$$
\mathrm{e}_{\mathrm{ijt}}=-\beta_{0 \mathrm{i}}+\beta_{1 \mathrm{i}} \mathrm{q}_{\mathrm{ijt}}, \quad \text { with } 0<\beta_{1 \mathrm{i}}<1
$$

The intercept $\left(\beta_{0 \mathrm{i}}\right)$ reflects technological progress that is exogenous to the sector, i.e. the negative sign is interpreted to mean that at zero output growth employment in the sector falls due to technical advance generated outside of the sector. The employment elasticity with respect to output growth in the sector is measured by the coefficient $\left(\beta_{1 i}\right)$.

Two sets of hypotheses have been tested for the nine sectors. The first hypothesis tests if there is a statistically significant positive relation between employment growth and output growth in the sector, while the second hypothesis tests if the estimate for the sectoral employment elasticity is significantly less than one. Conceptually, the latter is interpreted to be evidence for the existence of increasing returns, and alternatively a coefficient of unity on output growth would represent constant returns. Figure 1 provides a graphical representation of the productivity-growth relationship in employment growth (e) output growth (q) space. A line with 
unit slope and zero intercept depicts constant returns to scale (CRTS), i.e., the case where employment and output grow at the same rate. The dotted curve represents the case of increasing returns. Based on the productivity identity (iii), the difference between this curve and the CRTS line gives us the rate of growth of productivity (p). The null hypothesis of constant returns to scale (or unit slope) can be rejected if the estimated employment elasticity in the sector is positive and significantly less than one.

Figure 1: Graphical representation of the productivity-growth relationship

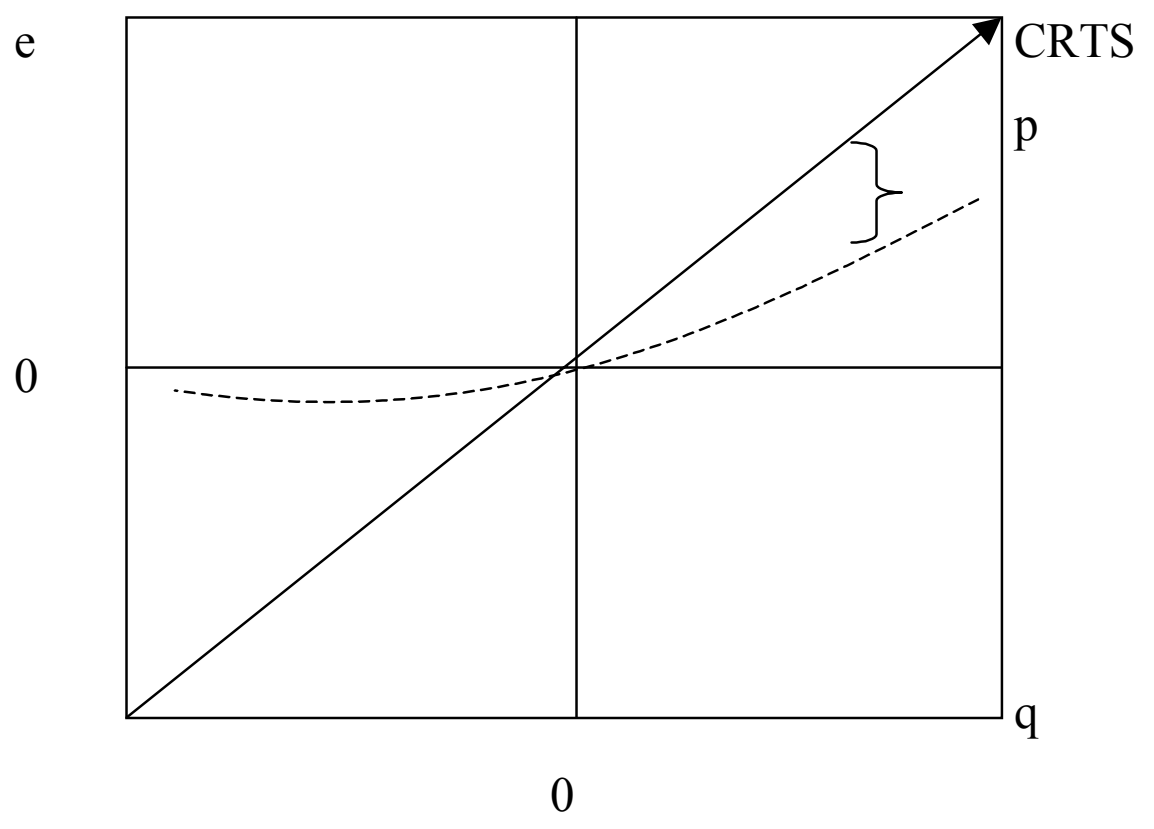

Source: Author.

As mentioned in the introduction to this paper, the Kaldor-Verdoorn Law states the existence of a stable positive relationship between the rate of growth of output and productivity growth in the long run. To take care of the cyclicality in the annual sectoral employment and output series the data was de-trended by taking five-year as well as ten-year averages based on log-growth rates. Sectoral productivity growth rates are then given by the difference between the 
rate of output growth and the rate of growth of employment in the sector due to the productivity identity $\mathrm{p}_{\mathrm{ijt}} \equiv \mathrm{q}_{\mathrm{ijt}}-\mathrm{e}_{\mathrm{ijt}}$ where $\mathrm{i}, \mathrm{j}$, and $\mathrm{t}$ stand for sector, country, and time, respectively. In other words, data for nine sectors are pooled from thirty country time series so that depending on availability every sector panel ends up having between 80 to 100 observations based on fiveyear growth rates and between 50 to 60 for ten-year growth rates.

It is in the sense of abstracting from the cyclical nature of the observations, that the resulting data set is not actually a "proper" panel because by definition in panel data both the time series and cross-section dimensions of the units of observation are pooled. Another important argument for de-trending the data series in this way is to mitigate the danger of conflating the estimates of the long-run Verdoorn Law with the so-called Okun's Law, which identified a negative statistical association between the change in unemployment and the rate of change of output over the business cycle (Okun, 1962). . In other words, the possibility of a bias in favor of Verdoorn's Law due to a conflation of the two laws exists only for the estimation of the relationship in high frequency time series data, which is why growth rates based on both five and ten-year averages are used for the OLS estimations.

The regression estimates for equation (3) based on ten-year and five-year growth rates are reported in tables $1 \mathrm{~A}$ and $1 \mathrm{~B}$, respectively. First, there are no significant differences between the estimated employment elasticities $\left(\beta_{1 \mathrm{i}}\right)$ based on five-year growth rates vs. ten-year growth rates. In both cases the sector estimates show a stable positive relationship between the rate of growth of employment and output growth. Furthermore, the constant returns hypothesis can be rejected for all nine sectors irrespective of whether five-year averages or ten-year averages are used in the estimations. This suggests that the employment and output growth rates based on five-year averages eliminate the cyclical element of the annual data series successfully. In the interest of preserving degrees of freedom the following parametric as well as nonparametric 
analysis of the Kaldor relationship is therefore based on five-year average rates of growth of output and employment.

Second, seven out of nine sector estimates with the exception of mining and commerce continue to be robust even when sequentially three and then another three outliers are removed from the sector panels (see table 1B). The magnitude of the estimated employment elasticity ranges from a low of 0.13 for commerce to a high of 0.55 for construction. The estimated employment elasticity of the manufacturing sector is 0.33 . The productivity identity (iii) above gives a Verdoorn coefficient $\left(\beta_{\mathrm{Ki}}\right)$ that is equal to $\beta_{\mathrm{Ki}}=\beta_{2 \mathrm{i}}=\left(1-\beta_{1 \mathrm{i}}\right)$ for sector $\mathrm{i}$. This results in a Verdoorn coefficient of 0.67 for manufacturing which together with public utilities ranks highest out of the nine sectors.

Regarding Kaldor's hypothesis test, for all nine sectors estimates of the employment elasticity with respect to output growth are significantly less than unity. Furthermore, this result remains robust after two iterations of removing influential observations from the sample.

While Kaldor $(1966,1975)$ proposed as the "sufficient" condition for evidence of economies to scale is a coefficient that is significantly less than unity, curiously he did not report the results from testing the hypothesis in his original study. This study used a comparable sector breakdown to the one used here. The missing calculations are compiled based on Kaldor's original estimates (see appendix table A.1 for details). All sectors with the exception of transport and communication show employment elasticities with respect to output growth that are significantly less than unity. Thus in seven out of eight cases we can reject the null hypothesis of constant returns to scale at the 5 percent confidence interval for one-tailed tests. These statistics based on Kaldor's original estimates of the Verdoorn Law similarly suggested substantial evidence for the prevalence of increasing returns at the sector level of the economy. 
Table 1: Sectoral employment elasticity $\left(\beta_{1 i}\right)$ for thirty developing countries (t-statistic and standard error as indicated in parenthesis)

A) Ten-year average growth rates

\begin{tabular}{|c|c|c|c|c|c|c|c|c|c|}
\hline & \multicolumn{3}{|c|}{$1^{\text {st }}$ run } & \multicolumn{3}{|c|}{$2^{\text {nd }}$ run } & \multicolumn{3}{|c|}{$3^{\text {rd }}$ run } \\
\hline & $\begin{array}{c}\text { Coefficient } \\
\boldsymbol{\beta}_{\mathbf{0}} \\
\text { (s.e.) }\end{array}$ & $\begin{array}{c}\text { Coefficient } \\
\boldsymbol{\beta}_{\mathbf{1}} \\
\text { (s.e.) }\end{array}$ & $\begin{array}{c}\text { Significant } \\
\text { from unity? } \\
\text { (t-stat.)* }\end{array}$ & $\begin{array}{c}\text { Coefficient } \\
\boldsymbol{\beta}_{0}{ }^{*} \\
\text { (s.e.) }\end{array}$ & $\begin{array}{c}\text { Coefficient } \\
\boldsymbol{\beta}_{1}^{*} \\
\text { (s.e.) }\end{array}$ & $\begin{array}{c}\text { Significant } \\
\text { from unity? } \\
\text { (t-stat.)* }\end{array}$ & $\begin{array}{c}\text { Coefficient } \\
\boldsymbol{\beta}_{0}{ }^{* \bullet} \\
\text { (s.e.) }\end{array}$ & $\begin{array}{c}\text { Coefficient } \\
\boldsymbol{\beta}_{1}{ }^{* \bullet} \\
\text { (s.e.) }\end{array}$ & $\begin{array}{c}\text { Significant } \\
\text { from unity? } \\
\text { (t-stat.)* }\end{array}$ \\
\hline agriculture & $\begin{array}{l}\mathbf{- 0 . 0 0 1 9} \\
(0.0053)\end{array}$ & $\begin{array}{c}\mathbf{0 . 4 9 2 2} \\
(0.1577)\end{array}$ & $\begin{array}{c}\text { yes } \\
(3.2200)\end{array}$ & $\begin{array}{c}\mathbf{0 . 0 0 0 4} \\
(0.0067)\end{array}$ & $\begin{array}{c}\mathbf{0 . 4 2 9 9} \\
(0.2206)\end{array}$ & $\begin{array}{c}\text { yes } \\
(2.5843)\end{array}$ & $\begin{array}{c}\mathbf{- 0 . 0 0 0 7} \\
(0.0057)\end{array}$ & $\begin{array}{c}\mathbf{0 . 4 2 7 0} \\
(0.1860)\end{array}$ & $\begin{array}{c}\text { yes } \\
(3.0806)\end{array}$ \\
\hline mining & $\begin{array}{c}\mathbf{0 . 0 0 3 6} \\
(0.0105)\end{array}$ & $\begin{array}{c}\mathbf{0 . 2 1 3 1} \\
(0.1435)\end{array}$ & $\begin{array}{c}\text { yes } \\
(5.4836)\end{array}$ & $\begin{array}{c}\mathbf{0 . 0 0 6 8} \\
(0.0080)\end{array}$ & $\begin{array}{c}\mathbf{0 . 0 4 3 6} \\
(0.1136)\end{array}$ & $\begin{array}{c}\text { yes } \\
(8.4190)\end{array}$ & $\begin{array}{c}\mathbf{0 . 0 0 8 3} \\
(0.0068)\end{array}$ & $\begin{array}{c}\mathbf{0 . 1 4 5 4} \\
(0.1119)\end{array}$ & $\begin{array}{c}\text { yes } \\
(7.6372)\end{array}$ \\
\hline manufacturing & $\begin{array}{c}\mathbf{0 . 0 1 6 9} \\
(0.0047)\end{array}$ & $\begin{array}{c}\mathbf{0 . 3 8 8 1} \\
(0.0817)\end{array}$ & $\begin{array}{c}\text { yes } \\
(7.4896)\end{array}$ & $\begin{array}{c}\mathbf{0 . 0 1 9 4} \\
(0.0042) \\
\end{array}$ & $\begin{array}{c}\mathbf{0 . 2 7 7 0} \\
(0.0750) \\
\end{array}$ & $\begin{array}{c}\text { yes } \\
(9.6400)\end{array}$ & $\begin{array}{c}\mathbf{0 . 0 1 3 0} \\
(0.0039) \\
\end{array}$ & $\begin{array}{c}\mathbf{0 . 3 6 2 9} \\
(0.0685) \\
\end{array}$ & $\begin{array}{c}\text { yes } \\
(9.3007)\end{array}$ \\
\hline public utilities & $\begin{array}{c}\mathbf{0 . 0 2 0 9} \\
(0.0119) \\
\end{array}$ & $\begin{array}{c}\mathbf{0 . 2 1 9 4} \\
(0.1586) \\
\end{array}$ & $\begin{array}{c}\text { yes } \\
(4.9218) \\
\end{array}$ & $\begin{array}{c}\mathbf{0 . 0 2 1 2} \\
(0.0097) \\
\end{array}$ & $\begin{array}{c}\mathbf{0 . 2 7 2 2} \\
(0.1378) \\
\end{array}$ & $\begin{array}{c}\text { yes } \\
(5.2816) \\
\end{array}$ & $\begin{array}{c}\mathbf{0 . 0 2 5 1} \\
(0.0097) \\
\end{array}$ & $\begin{array}{c}\mathbf{0 . 1 9 9 8} \\
(0.1401) \\
\end{array}$ & $\begin{array}{c}\text { yes } \\
(5.7116) \\
\end{array}$ \\
\hline construction & $\begin{array}{c}\mathbf{0 . 0 0 4 4} \\
(0.0073)\end{array}$ & $\begin{array}{c}\mathbf{0 . 6 4 5 2} \\
(0.1243)\end{array}$ & $\begin{array}{c}\text { yes } \\
(2.8544)\end{array}$ & $\begin{array}{c}\mathbf{0 . 0 0 3 8} \\
(0.0059)\end{array}$ & $\begin{array}{c}\mathbf{0 . 6 5 8 9} \\
(0.1013)\end{array}$ & $\begin{array}{c}\text { yes } \\
(3.3672)\end{array}$ & $\begin{array}{c}\mathbf{- 0 . 0 0 1 0} \\
(0.0057)\end{array}$ & $\begin{array}{c}\mathbf{0 . 7 8 3 0} \\
(0.1004)\end{array}$ & $\begin{array}{c}\text { yes } \\
(2.1614)\end{array}$ \\
\hline commerce & $\begin{array}{c}\mathbf{0 . 0 2 5 1} \\
(0.0073)\end{array}$ & $\begin{array}{c}\mathbf{0 . 2 4 6 9} \\
(0.1455)\end{array}$ & $\begin{array}{c}\text { yes } \\
(5.1759)\end{array}$ & $\begin{array}{c}\mathbf{0 . 0 3 0 2} \\
(0.0074)\end{array}$ & $\begin{array}{c}\mathbf{0 . 1 3 8 6} \\
(0.1559)\end{array}$ & $\begin{array}{c}\text { yes } \\
(5.5253)\end{array}$ & $\begin{array}{c}\mathbf{0 . 0 3 2 7} \\
(0.0059)\end{array}$ & $\begin{array}{c}\mathbf{0 . 1 1 1 7} \\
(0.1268)\end{array}$ & $\begin{array}{c}\text { yes } \\
(7.0055)\end{array}$ \\
\hline $\begin{array}{l}\text { transport \& } \\
\text { communication }\end{array}$ & $\begin{array}{c}\mathbf{0 . 0 2 0 5} \\
(0.0069)\end{array}$ & $\begin{array}{c}\mathbf{0 . 2 7 7 6} \\
(0.1076)\end{array}$ & $\begin{array}{c}\text { yes } \\
(6.7138)\end{array}$ & $\begin{array}{c}\mathbf{0 . 0 1 8 0} \\
(0.0056)\end{array}$ & $\begin{array}{c}\mathbf{0 . 2 9 0 8} \\
(0.0884)\end{array}$ & $\begin{array}{c}\text { yes } \\
(8.0226)\end{array}$ & $\begin{array}{c}\mathbf{0 . 0 1 5 5} \\
(0.0062)\end{array}$ & $\begin{array}{c}\mathbf{0 . 3 3 0 8} \\
(0.0955)\end{array}$ & $\begin{array}{c}\text { yes } \\
(7.0073)\end{array}$ \\
\hline FIRE & $\begin{array}{c}\mathbf{0 . 0 3 7 1} \\
(0.0072)\end{array}$ & $\begin{array}{c}\mathbf{0 . 4 5 5 3} \\
(0.1120)\end{array}$ & $\begin{array}{c}\text { yes } \\
(4.8634)\end{array}$ & $\begin{array}{c}\mathbf{0 . 0 2 2 2} \\
(0.0077)\end{array}$ & $\begin{array}{c}\mathbf{0 . 6 7 5 0} \\
(0.1307)\end{array}$ & $\begin{array}{c}\text { yes } \\
(2.4866)\end{array}$ & $\begin{array}{c}\mathbf{0 . 0 2 1 5} \\
(0.0069)\end{array}$ & $\begin{array}{c}\mathbf{0 . 7 2 6 2} \\
(0.1210)\end{array}$ & $\begin{array}{c}\text { yes } \\
(2.2628)\end{array}$ \\
\hline social services & $\begin{array}{c}\mathbf{0 . 0 2 3 0} \\
(0.0046)\end{array}$ & $\begin{array}{c}\mathbf{0 . 2 8 7 8} \\
(0.0907)\end{array}$ & $\begin{array}{c}\text { yes } \\
(7.8523) \\
(7.85\end{array}$ & $\begin{array}{c}\mathbf{0 . 0 2 4 0} \\
(0.0044)\end{array}$ & $\begin{array}{c}\mathbf{0 . 2 5 6 8} \\
(0.0880)\end{array}$ & $\begin{array}{c}\text { yes } \\
(8.4454)\end{array}$ & $\begin{array}{c}\mathbf{0 . 0 2 3 6} \\
(0.0038)\end{array}$ & $\begin{array}{c}\mathbf{0 . 2 2 6 7} \\
(0.0796) \\
\end{array}$ & $\begin{array}{c}\text { yes } \\
(9.7236)\end{array}$ \\
\hline
\end{tabular}


B) Five-year average growth rates

\begin{tabular}{|c|c|c|c|c|c|c|c|c|c|c|c|c|}
\hline & \multicolumn{9}{|c|}{ Without Fixed Effects } & \multicolumn{3}{|c|}{ Fixed Effects Included** } \\
\hline & \multicolumn{3}{|c|}{$1^{\text {st }}$ run } & \multicolumn{3}{|c|}{$2^{\text {nd }}$ run } & \multicolumn{3}{|c|}{$3^{\text {rd }}$ run } & & & \\
\hline & $\begin{array}{c}\text { Coefficient } \\
\boldsymbol{\beta}_{\mathbf{0}} \\
\text { (s.e.) }\end{array}$ & $\begin{array}{c}\text { Coefficient } \\
\boldsymbol{\beta}_{1} \\
\text { (s.e.) }\end{array}$ & $\begin{array}{l}\text { Significant } \\
\text { from unity? } \\
\text { (t-stat.)* }\end{array}$ & $\begin{array}{c}\text { Coefficient } \\
\boldsymbol{\beta}_{0^{*}} \\
\text { (s.e.) }\end{array}$ & $\begin{array}{c}\text { Coefficient } \\
\boldsymbol{\beta}_{\mathbf{1}}{ }^{*} \\
\text { (s.e.) }\end{array}$ & $\begin{array}{c}\text { Significant } \\
\text { from unity? } \\
\text { (t-stat.)* }\end{array}$ & $\begin{array}{c}\text { Coefficient } \\
\boldsymbol{\beta}_{0}{ }^{* *} \\
\text { (s.e.) }\end{array}$ & $\begin{array}{c}\text { Coefficient } \\
\boldsymbol{\beta}_{\mathbf{1}}{ }^{* \bullet} \\
\text { (s.e.) }\end{array}$ & $\begin{array}{c}\text { Significant } \\
\text { from } \\
\text { unity? } \\
\text { (t-stat.)* }\end{array}$ & $\begin{array}{c}\text { Coefficient } \\
\boldsymbol{\beta}_{0} \\
\text { (s.e.) }\end{array}$ & $\begin{array}{c}\text { Coefficient } \\
\boldsymbol{\beta}_{1} \\
\text { (s.e.) }\end{array}$ & $\begin{array}{c}\text { Significant } \\
\text { from unity? } \\
\text { (t-stat.)* }\end{array}$ \\
\hline agriculture & $\begin{array}{c}\mathbf{- 0 . 0 0 1 2} \\
(0.0051) \\
\end{array}$ & $\begin{array}{c}\mathbf{0 . 4 4 8 4} \\
(0.1310) \\
\end{array}$ & $\begin{array}{c}\text { yes } \\
(4.2107) \\
\end{array}$ & $\begin{array}{l}\mathbf{- 0 . 0 0 2 0} \\
(0.0054) \\
\end{array}$ & $\begin{array}{c}\mathbf{0 . 4 1 0 5} \\
(0.1556) \\
\end{array}$ & $\begin{array}{c}\text { yes } \\
(3.7886) \\
\end{array}$ & $\begin{array}{c}\mathbf{0 . 0 0 2 7} \\
(0.0051) \\
\end{array}$ & $\begin{array}{c}\mathbf{0 . 2 3 3 7} \\
(0.1457) \\
\end{array}$ & $\begin{array}{c}\text { yes } \\
(5.2594) \\
\end{array}$ & $\begin{array}{l}\mathbf{0 . 0 0 4 2} \\
(0.020) \\
\end{array}$ & $\begin{array}{c}\mathbf{0 . 2 0 7} \\
(0.139) \\
\end{array}$ & $\begin{array}{c}\text { yes } \\
(5.7050) \\
\end{array}$ \\
\hline mining & $\begin{array}{l}\mathbf{- 0 . 0 0 1 0} \\
(0.0116)\end{array}$ & $\begin{array}{c}\mathbf{0 . 5 1 3 9} \\
(0.1188)\end{array}$ & $\begin{array}{c}\text { yes } \\
(4.0918)\end{array}$ & $\begin{array}{c}\mathbf{0 . 0 0 6 3} \\
(0.0097)\end{array}$ & $\begin{array}{c}\mathbf{0 . 2 4 7 0} \\
(0.1193)\end{array}$ & $\begin{array}{c}\text { yes } \\
(6.3118)\end{array}$ & $\begin{array}{c}\mathbf{0 . 0 0 7 4} \\
(0.0067)\end{array}$ & $\begin{array}{c}\mathbf{0 . 1 6 0 3} \\
(0.0813)\end{array}$ & $\begin{array}{c}\text { yes } \\
(10.3284)\end{array}$ & $\begin{array}{l}\mathbf{- 0 . 0 0 5 9} \\
(0.053)\end{array}$ & $\begin{array}{c}\mathbf{0 . 5 4 9} \\
(0.134)\end{array}$ & $\begin{array}{c}\text { yes } \\
(3.3657)\end{array}$ \\
\hline manufacturing & $\begin{array}{c}\mathbf{0 . 0 1 6 4} \\
(0.0048)\end{array}$ & $\begin{array}{c}\mathbf{0 . 4 0 0 1} \\
(0.0776)\end{array}$ & $\begin{array}{c}\text { yes } \\
(7.7307)\end{array}$ & $\begin{array}{c}\mathbf{0 . 0 1 9 4} \\
(0.0041)\end{array}$ & $\begin{array}{c}\mathbf{0 . 3 6 2 0} \\
(0.0698)\end{array}$ & $\begin{array}{c}\text { yes } \\
(9.1404)\end{array}$ & $\begin{array}{c}\mathbf{0 . 0 1 8 3} \\
(0.0038)\end{array}$ & $\begin{array}{c}\mathbf{0 . 3 2 8 8} \\
(0.0658)\end{array}$ & $\begin{array}{c}\text { yes } \\
(10.2006)\end{array}$ & $\begin{array}{c}-\mathbf{- 0 . 0 0 6 2} \\
(0.022)\end{array}$ & $\begin{array}{c}\mathbf{0 . 4 4 5} \\
(0.116)\end{array}$ & $\begin{array}{c}\text { yes } \\
(4.7845)\end{array}$ \\
\hline public utilities & $\begin{array}{c}\mathbf{0 . 0 2 0 1} \\
(0.0104) \\
\end{array}$ & $\begin{array}{c}\mathbf{0 . 1 6 9 1} \\
(0.1297) \\
\end{array}$ & $\begin{array}{c}\text { yes } \\
(6.4063)\end{array}$ & $\begin{array}{c}\mathbf{0 . 0 1 5 9} \\
(0.0087)\end{array}$ & $\begin{array}{c}\mathbf{0 . 2 5 4 2} \\
(0.1095)\end{array}$ & $\begin{array}{c}\text { yes } \\
(6.8109)\end{array}$ & $\begin{array}{c}\mathbf{0 . 0 1 7 8} \\
(0.0072) \\
\end{array}$ & $\begin{array}{c}\mathbf{0 . 2 5 5 3} \\
(0.0903) \\
\end{array}$ & $\begin{array}{c}\text { yes } \\
(8.2469) \\
\end{array}$ & $\begin{array}{l}\mathbf{0 . 0 2 4 3} \\
(0.026)\end{array}$ & $\begin{array}{c}\mathbf{0 . 2 5 6} \\
(0.112)\end{array}$ & $\begin{array}{c}\text { yes } \\
(6.6429)\end{array}$ \\
\hline construction & $\begin{array}{c}\mathbf{0 . 0 0 8 8} \\
(0.0071) \\
\end{array}$ & $\begin{array}{c}\mathbf{0 . 4 6 1 3} \\
(0.0752)\end{array}$ & $\begin{array}{c}\text { yes } \\
(7.1636)\end{array}$ & $\begin{array}{c}\mathbf{0 . 0 1 5 2} \\
(0.0054)\end{array}$ & $\begin{array}{c}\mathbf{0 . 4 9 5 8} \\
(0.0578)\end{array}$ & $\begin{array}{c}\text { yes } \\
(8.7231)\end{array}$ & $\begin{array}{c}\mathbf{0 . 0 1 7 2} \\
(0.0051)\end{array}$ & $\begin{array}{c}\mathbf{0 . 5 5 0 4} \\
(0.0655) \\
\end{array}$ & $\begin{array}{c}\text { yes } \\
(6.8641)\end{array}$ & $\begin{array}{l}\mathbf{0 . 0 3 4 6} \\
(0.034)\end{array}$ & $\begin{array}{c}\mathbf{0 . 4 5 5} \\
(0.090)\end{array}$ & $\begin{array}{c}\text { yes } \\
(6.0556)\end{array}$ \\
\hline commerce & $\begin{array}{c}\mathbf{0 . 0 2 5 2} \\
(0.0062) \\
\end{array}$ & $\begin{array}{c}\mathbf{0 . 2 4 2 8} \\
(0.1133) \\
\end{array}$ & $\begin{array}{c}\text { yes } \\
(6.6831) \\
\end{array}$ & $\begin{array}{c}\mathbf{0 . 0 2 6 3} \\
(0.0061) \\
\end{array}$ & $\begin{array}{c}\mathbf{0 . 1 9 5 0} \\
(0.1125) \\
\end{array}$ & $\begin{array}{c}\text { yes } \\
(7.1556) \\
\end{array}$ & $\begin{array}{c}\mathbf{0 . 0 3 0 2} \\
(0.0057) \\
\end{array}$ & $\begin{array}{c}\mathbf{0 . 1 3 0 6} \\
(0.1076) \\
\end{array}$ & $\begin{array}{c}\text { yes } \\
(8.0799) \\
\end{array}$ & $\begin{array}{l}\mathbf{0 . 0 3 4 7} \\
(0.021) \\
\end{array}$ & $\begin{array}{c}\mathbf{0 . 2 1 2} \\
(0.131) \\
\end{array}$ & $\begin{array}{c}\text { yes } \\
(6.0153) \\
\end{array}$ \\
\hline $\begin{array}{l}\text { transport \& } \\
\text { communication }\end{array}$ & $\begin{array}{c}\mathbf{0 . 0 1 7 4} \\
(0.0084)\end{array}$ & $\begin{array}{c}\mathbf{0 . 3 0 9 3} \\
(0.1231)\end{array}$ & $\begin{array}{c}\text { yes } \\
(5.6109)\end{array}$ & $\begin{array}{c}\mathbf{0 . 0 1 1 6} \\
(0.0058)\end{array}$ & $\begin{array}{c}\mathbf{0 . 4 2 0 7} \\
(0.0834)\end{array}$ & $\begin{array}{c}\text { yes } \\
(6.9460)\end{array}$ & $\begin{array}{c}\mathbf{0 . 0 0 8 3} \\
(0.0057)\end{array}$ & $\begin{array}{c}\mathbf{0 . 4 6 1 2} \\
(0.0841)\end{array}$ & $\begin{array}{c}\text { yes } \\
(6.3482)\end{array}$ & $\begin{array}{l}\mathbf{0 . 0 3 0 2} \\
(0.015)\end{array}$ & $\begin{array}{c}\mathbf{0 . 3 1 1} \\
(0.119)\end{array}$ & $\begin{array}{c}\text { yes } \\
(5.7899)\end{array}$ \\
\hline FIRE & $\begin{array}{c}\mathbf{0 . 0 4 5 6} \\
(0.0099) \\
\end{array}$ & $\begin{array}{c}\mathbf{0 . 2 4 2 8} \\
(0.1298) \\
\end{array}$ & $\begin{array}{c}\text { yes } \\
(5.8336) \\
\end{array}$ & $\begin{array}{c}\mathbf{0 . 0 3 5 4} \\
(0.0079) \\
\end{array}$ & $\begin{array}{c}\mathbf{0 . 4 8 7 1} \\
(0.1187) \\
\end{array}$ & $\begin{array}{c}\text { yes } \\
(4.3209) \\
\end{array}$ & $\begin{array}{c}\mathbf{0 . 0 3 6 7} \\
(0.0070) \\
\end{array}$ & $\begin{array}{c}\mathbf{0 . 4 6 8 7} \\
(0.1095) \\
\end{array}$ & $\begin{array}{c}\text { yes } \\
(4.8521) \\
\end{array}$ & $\begin{array}{l}\mathbf{0 . 0 4 7 2} \\
(0.023) \\
\end{array}$ & $\begin{array}{c}\mathbf{0 . 1 5 1} \\
(0.161) \\
\end{array}$ & $\begin{array}{c}\text { yes } \\
(5.2733) \\
\end{array}$ \\
\hline social services & $\begin{array}{c}\mathbf{0 . 0 2 4 7} \\
(0.0040)\end{array}$ & $\begin{array}{c}\mathbf{0 . 2 2 0 3} \\
(0.0679)\end{array}$ & $\begin{array}{c}\text { yes } \\
(11.4831)\end{array}$ & $\begin{array}{c}\mathbf{0 . 0 2 1 3} \\
(0.0036)\end{array}$ & $\begin{array}{c}\mathbf{0 . 3 1 5 1} \\
(0.0624)\end{array}$ & $\begin{array}{c}\text { yes } \\
(10.9759)\end{array}$ & $\begin{array}{c}\mathbf{0 . 0 2 2 7} \\
(0.0035)\end{array}$ & $\begin{array}{c}\mathbf{0 . 3 0 1 8} \\
(0.0631)\end{array}$ & $\begin{array}{c}\text { yes } \\
(11.0649)\end{array}$ & $\begin{array}{l}\mathbf{0 . 0 2 4 2} \\
(0.010)\end{array}$ & $\begin{array}{c}\mathbf{0 . 3 0 7} \\
(0.078)\end{array}$ & $\begin{array}{c}\text { yes } \\
(8.8846)\end{array}$ \\
\hline
\end{tabular}

Notes:

-After removing three worst outliers. S-PLUS routinely performs tests to identify influential outliers during OLS regression. Most commonly, the change in an OLS estimate resulting from omitting the ith observation is tested. The test results for identifying influential observations did not vary with the techniques performed, so here Cook's

Distance was used over the three estimation runs.

* After removing six worst outliers as above.

* Significant at 5 percent confidence in one-tailed test.

**Dummy coefficients estimates are available on request.

Source: Author's calculations based on sample described in Appendix B. 
Another potential problem that has not been dealt with in the linear estimations so far is the issue of omitted heterogeneity. I added fixed time and country effects in the linear estimations of the nine sector panels. Table 1B compares the sector estimations without fixed effects to those that include fixed effects. Again we find a stable positive relationship between the rate of growth of employment and the rate of growth of output when fixed effects are included. Kaldor's sufficient null hypothesis of constant returns to scale can also be rejected for the nine sector estimates. These findings based on the linear estimation of the Verdoorn relation thus suggest robust evidence for increasing returns at the sector level of the developing economy.

\subsection{Differences in employment elasticities across sectors}

Based on the linear estimations presented in the previous section, the question of whether there are significant differences between the estimated employment elasticity for the individual sectors will be examined next. The appropriate statistical test for a significant difference between regression coefficients and the tested hypotheses are described in the notes to table 2 . The test considers a pair of coefficients at a time. The computed critical values are presented in a matrix that ranks the sectors according to the magnitude of their estimated employment elasticity.

By definition, the sectors with extreme high or low magnitude in the estimated employment elasticity have a relatively higher probability for the null hypothesis to be rejected than sectors with average coefficients (see notes in table 2). The most consistent pattern of significant differences from the other sectors at the upper extreme is found for the construction sector followed by FIRE, and transport and communication. At the low end of the range of magnitudes we find commerce, mining, and agriculture. In terms of the predictions of the Kaldor-Verdoorn Law, it is noteworthy that the estimated employment elasticity for the 
Table 2: Significant differences between sectoral employment elasticities (critical values)

\begin{tabular}{|c|c|c|c|c|c|c|c|c|c|}
\hline & construction & FIRE & $\begin{array}{c}\text { transport \& } \\
\text { communication }\end{array}$ & manufacturing & $\begin{array}{c}\text { social } \\
\text { services }\end{array}$ & public utilities & agriculture & mining & commerce \\
\hline construction & NA & 0.64 & 0.84 & $2.39 * * *$ & $3.00 * * *$ & $2.65 * * *$ & $1.98 * *$ & $3.74 * * *$ & $3.33 * * *$ \\
\hline FIRE & 0.64 & NA & 0.05 & 1.10 & $1.32 *$ & $1.50 *$ & 1.29 & $2.26^{* *}$ & $2.20 * *$ \\
\hline $\begin{array}{l}\text { transport \& } \\
\text { communication }\end{array}$ & 0.84 & 0.05 & NA & 1.24 & $1.52 *$ & $1.67 * *$ & $1.35^{*}$ & $2.57 * * *$ & $2.42 * * *$ \\
\hline manufacturing & $2.39 * * *$ & 1.10 & 1.24 & NA & 0.30 & 0.66 & 0.59 & $1.61 *$ & $1.57 *$ \\
\hline social services & $3.00 * * *$ & $1.32 *$ & $1.52 *$ & 0.30 & NA & 0.42 & 0.43 & $1.37 *$ & $1.37 *$ \\
\hline public utilities & $2.65 * * *$ & $1.50 *$ & $1.67 * *$ & 0.66 & 0.42 & NA & 0.13 & 0.78 & 0.89 \\
\hline agriculture & $1.98 * *$ & 1.29 & $1.35^{*}$ & 0.59 & 0.43 & 0.13 & NA & 0.44 & 0.57 \\
\hline mining & $3.74 * * *$ & $2.26 * *$ & $2.57 * * *$ & $1.61^{*}$ & $1.37 *$ & 0.78 & 0.44 & NA & 0.22 \\
\hline commerce & $3.33^{* * *}$ & $2.20 * *$ & $2.42 * * *$ & $1.57 *$ & $1.37 *$ & 0.89 & 0.57 & 0.22 & NA \\
\hline
\end{tabular}

Notes:

Under the assumption of normal distribution, $\beta_{1 \mathrm{i}} \sim \mathrm{N}\left(\beta_{1 \mathrm{i}}, \mathrm{V}\left(\beta_{1 \mathrm{i}}\right)\right.$, to test whether two regression coefficients, $\beta_{1}$ and $\beta_{2}$, drawn from samples of sizes $\mathrm{n}_{1}$ and $\mathrm{n}_{2}$, differ significantly from each other, critical values $\left(\mathrm{z}_{1,2}\right)$ are computed as follows. With $\beta_{11}-\beta_{12} \sim \mathrm{N}\left(\beta_{11}-\beta_{12}, \mathrm{~V}\left(\beta_{11}\right)+\mathrm{V}\left(\beta_{12}\right)\right)$,

$z_{1,2}=\frac{\beta_{11}-\beta_{12}}{\sqrt{V\left(\beta_{11}\right)+V\left(\beta_{12}\right)}} \sim \mathrm{N}(0,1)$

The null hypothesis $\mathrm{H}_{0}: \beta_{11}=\beta_{12}$ and $\mathrm{H}_{1}: \beta_{11}>\beta_{12}$. The following are critical values $\left(\mathrm{z}_{1,2}\right)$ from the t-statistic for a one-tailed test:

* Significant at the 0.10 level $\mathrm{z}>1.30$

**Significant at the 0.05 level $\mathrm{z}>1.67$

$* * *$ Significant at the 0.01 level $\mathrm{z}>2.39$

Source: Author's calculations.

manufacturing sector is only significantly different from that of the construction sector, mining, and commerce.

For nineteen out of thirty-six pairs of sectors the estimated coefficients are significantly different from each other. The finding presents substantial evidence that patterns of productivity growth vary across sectors underscoring the usefulness of growth analysis at a level of aggregation lower than macroeconomic variables. 


\section{Nonlinear estimation of sectoral employment elasticities}

\subsection{Statistical data smoothing and the Verdoorn Law}

There is an economic as well as a statistical motivation for the use of data smoothing techniques in the examination of the Verdoorn relation. First, the Verdoorn Law has commonly been assumed as a constant-parameter function without any compelling empirical or theoretical justification. By employing nonparametric procedures this section utilizes the sectoral evidence to examine the statistical regularities of the Verdoorn relation in developing countries. It is plausible to expect that the effect of economies of scale on productivity growth may diminish at relatively high output growth rates as Vaciago (1975) has found for the advanced economies of the 1950s and 1960s. Second, the exercise of data smoothing has the benefit of visualizing data regularities and thereby serves as an additional tool to detect possible problems of statistical robustness due to heterogeneity of the empirical evidence.

For the data smoothing exercise local regression analysis was performed in Locfit. $\frac{8}{8}$ Local regression as a statistical method is largely due to the "Loess" and "Lowess" procedures. Loess is an acronym for locally weighted regression (Jacoby, 1997). Essentially, Loess performs a series of robust weighted regressions at each of $\mathrm{m}$ different locations or evaluation points $\left(\mathrm{v}_{\mathrm{j}}\right.$, with $\mathrm{j}$ running from 1 to $\mathrm{m}$ ) along the $\mathrm{x}$ variable's range; each regression uses only the subset of observations that fall close to that evaluation point on the horizontal axis. That is for each fitting point $\mathrm{v}_{\mathrm{j}}$ a locally weighted least squares criterion is considered. The coefficients from each local regression are used to generate a predicted or fitted value, $g\left(v_{j}\right)$. The $m$ different points $\left(v_{j}, g\left[v_{j}\right]\right)$ are plotted, and adjacent points are connected by line segments to produce the final smooth curve.

A bandwidth "alpha" (i.e. the size of the sliding window) controls the smoothness of the fit. A large alpha may result in oversmoothing, or miss important features in the data, while a 
small alpha may result in a fit that is too noisy. A simple procedure to check the robustness of the choice of the bandwidth is by visual inspection of the residual plots of the local regression.

Figure 2 shows smooth curves based on local regressions that were performed using the sector data. The estimates for the sectoral employment elasticities with respect to output growth are presented by solid curves in the nine panels of the figure. ${ }^{19}$ The circles in the panels mark sectoral observations. The standard errors of the local regressions are shown by two dotted lines parallel to the smooth curves.

The findings can be summarized as follows. First, the local regression curves exhibit a regular nonlinear pattern of positive relationships between employment growth and output growth for all nine sectors.

Second, a 45-degree line was added to each of the nine graphs in order to visualize constant returns represented by its slope of one and zero intercept. A smooth curve with a slope that is flatter than the 45-degree line reflects the existence of increasing returns in the sector. Thus, the local regression fits of figure 2 show a regular pattern of increasing returns across all nine sectors.

Moreover, the results from the nonlinear estimation reflect robust sectoral relationships in the sense that the slope of the smooth curve for all nine sectors stays flatter than the 45-degree line throughout. Thus these estimations confirm the earlier findings based on least-squares regression and suggest strong evidence for increasing returns at the sectoral level of the economy. 
Figure 2: Sectoral employment growth with respect to output growth in developing countries, 1970s-1990s
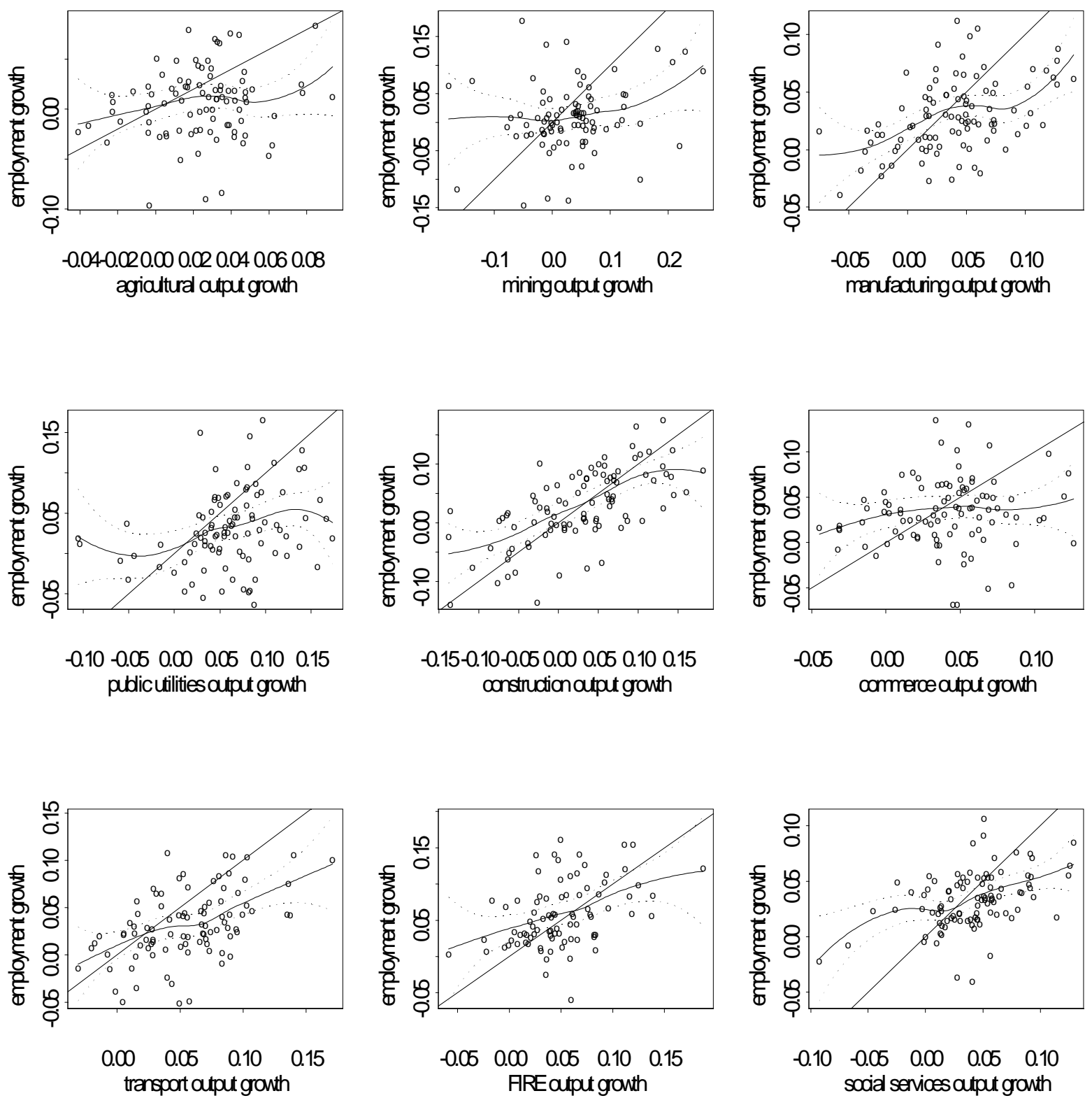

Note:

Smooth fits for sectoral increasing returns are predicted in locfit with a bandwidth of alpha equal .8 based on developing country sample. Solid curve and dotted lines show smooth fit and standard error, respectively. A solid 45-degree line represents constant returns to scale to visualize the magnitude of increasing returns in the sector.

Source: See data appendix. 


\subsection{Predicted sectoral employment elasticities: nonlinear estimations}

For a range of output growth rates (from -5 to 13 percent), sectoral employment growth rates were generated in Locfit and used to calculate predicted sectoral employment elasticities. This exercise will allow us to inspect as in section 3.3 the differences in the statistical patterns across sectors, this time on the basis of nonparametric estimations.

The results are summarized in table 3. Note, however, that the predicted elasticities for the extreme values of the range of output growth rates are less reliable due to relatively big standard errors. As in the case of the linear estimates, the Verdoorn coefficient (or the productivity elasticity with respect to output growth) can be computed by subtracting unity minus the predicted employment elasticity for the sector.

Table 3: Sectoral employment elasticities: nonlinear estimations

\begin{tabular}{|c|c|c|c|c|c|c|c|c|c|c|}
\hline $\begin{array}{l}\text { Sectoral output } \\
\text { (annual growth rate) }\end{array}$ & $-5.00 \%$ & $-3.00 \%$ & $-1.00 \%$ & $1.00 \%$ & $3.00 \%$ & $5.00 \%$ & $7.00 \%$ & $9.00 \%$ & $11.00 \%$ & $13.00 \%$ \\
\hline agriculture & 0.38 & 0.33 & 0.15 & 0.78 & 0.44 & 0.14 & 0.20 & 0.40 & 0.64 & 0.81 \\
\hline mining & -0.14 & -0.13 & -0.20 & 0.35 & 0.24 & 0.22 & 0.22 & 0.21 & 0.19 & 0.19 \\
\hline manufacturing & 0.05 & -0.10 & -1.25 & 2.34 & 1.13 & 0.76 & 0.52 & 0.41 & 0.44 & 0.52 \\
\hline public utilities & 0.05 & 0.10 & -0.24 & 1.08 & 0.77 & 0.63 & 0.49 & 0.47 & 0.45 & 0.42 \\
\hline construction & 0.34 & 0.11 & -0.96 & 2.17 & 1.12 & 0.94 & 0.87 & 0.82 & 0.76 & 0.69 \\
\hline commerce & -0.12 & -0.59 & -2.70 & 3.38 & 1.25 & 0.79 & 0.53 & 0.41 & 0.37 & 0.38 \\
\hline transport \& com. & 0.46 & 0.31 & -0.39 & 1.59 & 0.87 & 0.61 & 0.49 & 0.54 & 0.55 & 0.56 \\
\hline FIRE & -0.30 & -0.83 & -3.44 & 4.26 & 1.71 & 1.18 & 0.94 & 0.89 & 0.83 & 0.78 \\
\hline social services & -0.28 & -0.74 & -2.55 & 2.35 & 0.94 & 0.78 & 0.65 & 0.56 & 0.52 & 0.51 \\
\hline
\end{tabular}

Source: Author's calculations. 
First, it is important to point out that the Verdoorn elasticity for the manufacturing sector reaches the magnitude of 0.5 that was found by Kaldor (1966) only at high industrial output growth rates (about 7 percent). At 5 percent manufacturing output growth the Verdoorn coefficient is considerably lower at just 0.25 .

Second, the reverse pattern can be found for agriculture where the employment elasticity increases at high output growth rates (around 10 percent), which implies a diminishing Verdoorn coefficient as output expands faster. The deceleration of economies to scale in agriculture can also be visualized from the local regression curve shown in figure 2, for which the slope gets flatter at high output growth rates.

Other sectoral patterns that can be detected from the estimates of table 3 are a consistently low employment coefficient in the mining sector, and a consistently high coefficient in construction. In fact, the construction sector is a notable exception to the overall sectoral pattern. In the intermediate range of growth rates the employment elasticity for construction appears to exhibit constant returns to scale.

It should be stressed that these findings based on predicted employment elasticities can only suggest statistical regularity in the empirical relation of productivity growth and the rate of growth of output across sectors, they cannot offer any more insights into the underlying functional form of the sectoral relations. Thus, any explanations as to the reasons for the differences in sector patterns would be speculative at this stage of the analysis.

\section{Conclusions and future research}

This paper offered a Kaldorian interpretation for patterns of productivity growth at the sector level of the economy. Empirical regularities across sectors were identified based on a historical data set of thirty developing countries. Both for linear and nonlinear estimations, the statistical 
evidence shows robust positive relationships between the rate of growth of employment and the rate of growth of output for all nine sectors under investigation. Most importantly, the estimated sectoral employment elasticities with respect to output growth are significantly less than unity suggesting strong support for the Verdoorn Law in developing countries, and therefore, more generally for models of endogenous growth. Furthermore, this evidence suggests that increasing returns to scale are not merely a macroeconomic phenomenon, but in fact they are prevalent at the sector level of the economy. Moreover, substantial heterogeneity of the statistical regularities in productivity growth across sectors underscores the need to focus research efforts at levels lower than macroeconomic aggregation, which is not commonly used in studies on economic growth.

In light of the identified statistical regularities at the sector level of productivity growth the Kaldorian interpretation offered in the paper emphasizes the role of increasing returns in interaction with unlimited supplies of labor. Productivity growth appears to be not only countryspecific as Kaldor suggested but also sector or industry-specific in accordance with established stylized patterns of aggregate productivity divergence as well as within-sector divergence across countries.

Much more research remains in order to explain aggregate productivity growth differences. For instance, this paper focused its attention on empirical regularities of productivity growth at the within-sector level of the economy, holding constant any betweensector interaction or technology diffusion. However, the role of sectors and sectoral technology spillovers in aggregate productivity growth are expected to be important for developing countries undergoing rapid structural transformations. Future work should address these issues by compiling data on inputs and output for disaggregated sectors across countries. 
Appendix A: Kaldor's empirical findings for the Verdoorn Law

Kaldor originally estimated the Verdoorn Law for seven sectors across twelve OECD countries for the period from 1953-4 to 1963-4. Table A.1 summarizes the estimates based on equations (1) and (2) from section 2 for manufacturing and six additional sectors of the economy.

All sectors with the exception of transport and communication show employment elasticities with respect to output growth that are significantly less than unity (see right hand column). Thus in seven out of eight cases we can reject the null hypothesis of constant returns to scale. These results were curiously left unreported in Kaldor (1966, pp. 124-128).

For the manufacturing sector the productivity elasticity with respect to output growth or the Verdoorn coefficient $\left(\beta_{\mathrm{K} 1}\right)$ is about one half. A similar Verdoorn relation to that in industry is also found for public utilities, and the construction and mining sectors. On the other hand, agriculture and commerce show no such relation. In both of these sectors productivity growth shows a substantial trend factor independent of the growth of total output. Finally, for commerce the productivity elasticity with respect to output growth is not significantly different from zero, in other words there exists no statistically significant relationship between the rate of growth of employment and output in the sector.

Table A.1: Kaldor's estimates of the Verdoorn relation

\begin{tabular}{|c|c|c|c|c|c|}
\hline & \multicolumn{2}{|c|}{ (1) } & \multicolumn{3}{|c|}{ (2) } \\
\hline & $\begin{array}{l}\text { Coefficient } \\
\boldsymbol{\alpha}_{\mathbf{K} 1}\end{array}$ & $\begin{array}{c}\text { Coefficient } \\
\boldsymbol{\beta}_{\mathbf{K} 1} \\
\text { (s.e.) }\end{array}$ & $\begin{array}{l}\text { Coefficient } \\
-\boldsymbol{\alpha}_{\mathbf{K} \mathbf{2}}\end{array}$ & $\begin{array}{l}\text { Coefficient } \\
\boldsymbol{\beta}_{\mathbf{K} 2} \\
\text { (s.e.) }\end{array}$ & $\begin{array}{l}\text { Significant } \\
\text { from unity? } \\
\text { (t-stat.)* }^{*}\end{array}$ \\
\hline agriculture & 2.7 & $\begin{array}{c}\mathbf{1 . 0 4 1} \\
(0.155)\end{array}$ & -2.7 & $\begin{array}{l}\mathbf{- 0 . 0 5 6} \\
(0.155) \\
\end{array}$ & $\begin{array}{c}\text { yes } \\
(6.0903)\end{array}$ \\
\hline mining & 4.1 & $\begin{array}{c}\mathbf{0 . 6 7 1} \\
(0.153)\end{array}$ & -4.1 & $\begin{array}{c}\mathbf{0 . 3 2 9} \\
(0.153)\end{array}$ & $\begin{array}{c}\text { yes } \\
(4.3856)\end{array}$ \\
\hline manufacturing & 1.0 & $\begin{array}{r}\mathbf{0 . 4 8 4} \\
(0.070) \\
\end{array}$ & -1.0 & $\begin{array}{c}\mathbf{0 . 5 1 6} \\
(0.070) \\
\end{array}$ & $\begin{array}{c}\text { yes } \\
(6.9143) \\
\end{array}$ \\
\hline public utilities & 2.7 & $\begin{array}{c}\mathbf{0 . 4 1 9} \\
(0.154)\end{array}$ & -2.7 & $\begin{array}{c}\mathbf{0 . 5 7 7} \\
(0.154)\end{array}$ & $\begin{array}{c}\text { yes } \\
(2.7468)\end{array}$ \\
\hline construction & -0.5 & $\begin{array}{c}\mathbf{0 . 5 7 2} \\
(0.092)\end{array}$ & 0.5 & $\begin{array}{c}\mathbf{0 . 4 2 8} \\
(0.092)\end{array}$ & $\begin{array}{c}\text { yes } \\
(6.2173)\end{array}$ \\
\hline commerce & -1.7 & $\begin{array}{c}\mathbf{0 . 9 5 3} \\
(0.098) \\
\end{array}$ & 1.7 & $\begin{array}{c}\mathbf{0 . 0 5 6} \\
(0.098) \\
\end{array}$ & $\begin{array}{c}\text { yes } \\
(9.6327) \\
\end{array}$ \\
\hline $\begin{array}{l}\text { transport \& } \\
\text { communication }\end{array}$ & 2.3 & $\begin{array}{c}\mathbf{0 . 2 2 4} \\
(0.252)\end{array}$ & -2.3 & $\begin{array}{c}\mathbf{0 . 7 7 6} \\
(0.252)\end{array}$ & $\begin{array}{c}\text { no } \\
(0.8889)\end{array}$ \\
\hline
\end{tabular}

Note:

*Statistically significant at 5 percent in one-tailed test.

Source: Compiled from Kaldor (1966), and author's calculations. 


\section{Appendix B: Data sources}

Sectoral data for real value added

The country data for value added used in the paper is taken from the annual series "Gross Domestic Product by Kind of Activity (at constant prices)" of the U.N. National Accounts which was provided by the United Nations Statistics Division, New York. The data is in national currency and is arranged according to the International Standard Industry Classification (ISIC) code at the one-digit level, i.e. it covers nine main "activities" or sectors. The sum total of these nine sectors' real value added (excluding "producers of government services") gives the gross domestic product (GDP) at factor prices. For most countries, the series covers the period from the mid-1970s to 1993 .

For Brazil, sectoral output data is taken from Estadisticas Historicas do Brasil: Series Economicas, demograficas e sociais de 1550 a 1988, 2nd ed., Instituto Brasileiro de Geografia e Estadistica (IBGE) 1990.

\section{Sectoral data for employment}

The country data for sectoral employment was provided by the International Labour Office, Geneva, also published in Yearbook of Labour Statistics. It is an annual series that covers (at maximum) the period from 1975 to 1993. Just like the data from the U.N. National Accounts, the series is disaggregated at the one-digit level of ISIC.

Because its country coverage is smaller than the output series used in the paper, additional sectoral employment data was taken from national sources for Peru (Compendio Estadístico) and Mexico (Sistema de Cuentas Nacionales de México).

\section{Sectoral labor productivity}

Sectoral labor productivity for the countries was computed by combining the two data series of sectoral value added and employment described above. In other words, sectoral productivity is defined as sectoral value added (here in national currency) divided by the number of persons employed in the sector.

Countries covered

\begin{tabular}{|l|l|}
\hline Sub-Saharan Africa & $\begin{array}{l}\text { Botswana, Ghana, Kenya, Malawi, Sierra Leone, South Africa, Zambia, } \\
\text { Zimbabwe }\end{array}$ \\
\hline $\begin{array}{l}\text { Latin America and the } \\
\text { Caribbean }\end{array}$ & $\begin{array}{l}\text { Bolivia, Brazil, Chile, Colombia, Costa Rica, Guatemala, Mexico, } \\
\text { Panama, Peru, Puerto Rico, Venezuela }\end{array}$ \\
\hline South and East Asia & $\begin{array}{l}\text { India, Indonesia, Korea, Malaysia, Myanmar, Philippines, Singapore, } \\
\text { Sri Lanka, Thailand }\end{array}$ \\
\hline Other & Turkey, Jordan \\
\hline
\end{tabular}


${ }^{1}$ Note that the authors find convergence in sectoral productivity levels across countries to dominate in the non-
tradables or non-manufacturing sectors of the economy, in particular the services sector, where international
technology diffusion is expected to be limited.
${ }^{2}$ An exhaustive account of the controversy is beyond the scope of this paper. For review see e.g. the symposium on
Nicholas Kaldor in the Journal of Post Keynesian Economics, in particular Thirlwall (1983) and McCombie (1983).
${ }^{3}$ A notable early exception to using a linear specification in the estimation of the Verdoorn Law is Vaciago (1975)
who found evidence for "decreasing" increasing returns across countries, i.e., a diminishing effect of higher rates of
output growth on productivity. More recently, there has been a growing body of literature using a variety of
nonparametric procedures called "frontier analysis," which allow to estimate the upper boundary of a production set
without prior specification of a functional form. See for example Destefanis (1999) for a very careful illustration of applying these statistical procedures to the investigation of Verdoorn's Law in 52 economies.

${ }^{4}$ In his famous 1949 article Verdoorn suggested a "fairly constant relation over a long period between the growth of labor productivity and the volume of industrial production" (1949, 1988, pp. 199). From analyzing historical series for industry, he found that the average value of the elasticity of productivity with respect to output is approximately 0.5. Essentially, Verdoorn's analysis attempted to address long-term economic planning questions of, for instance, the requirement of industrial output expansion in order to absorb a certain availability of labor. The elasticity of productivity with respect to output is given by the ratio of labor productivity to output; henceforth the Verdoorn ratio as opposed to the Verdoorn coefficient, which is the estimate from regressing productivity growth on output growth. Empirically, the Verdoorn ratio fell within "reasonable" limits across countries (between 0.41 and 0.57 ). ${ }^{5}$ In the many studies that followed similar results were reported using cross-industry, time series and regional data for advanced countries and, though much less systematically, for developing countries (see e.g. McCombie and de Ridder, 1984; Gomulka, 1983; Cripps and Tarling, 1973).

${ }^{6}$ Verdoorn wrote: "one could have expected a priori to find a correlation between labor productivity and output, given that the division of labor only comes about through increases in the volume of production; therefore the expansion of production creates the possibility of further rationalization which has the same effect as mechanization" (1949, 1988; Thirlwall's English translation, p. 199).

${ }^{7}$ For the derivation of the output-productivity growth relation from a Cobb-Douglas production function Verdoorn $(1949,1980)$ assumed steady-state growth which allows a straightforward translation of the empirical estimates into a measure of (exogenous) technical change (Ros, 2000). The steady-state assumption does not provide a meaningful framework for interpretation of the law in the context of developing countries.

${ }^{8}$ Evidence for limited factor substitutability in developing countries is presented in Amsden and van der Hoeven (1996) and Pieper (2000).

${ }^{9}$ The law can also be specified to include capital stock in order to reflect a production relation such as a form of technical progress function. This allows a separation to be made between the growth of productivity due to the greater use of machinery and that resulting from increasing returns to scale. The inclusion of the rate of growth of the capital stock does not lead to a revision of the interpretation of the law as long as the capital-labor ratio is assumed constant in the short run. In previous studies the omission of capital has been shown not to affect the robustness of the Verdoorn estimates (see e.g. Michl, 1985).

${ }^{10} \mathrm{Cf}$. Bairam (1987) for an exhaustive survey.

${ }^{11}$ Rowthorn's reformulation is specified as $p=\alpha+\beta_{R} e$ with $\beta_{R}>0$.

${ }^{12}$ Mathematically speaking, there are four different specifications of the Verdoorn relation. In addition to Kaldor's and Rowthorn's already mentioned, alternatively Cripps and Tarling (1973) specified the model as $\mathrm{q}=\alpha+\beta_{\mathrm{CT}} \mathrm{e}$ where output growth depends on employment growth.

${ }^{13} \mathrm{Cf}$. the data appendix for more details on data sources and countries covered.

${ }^{14} \mathrm{~A}$ complete catalog of data sources and quality ratings for country data included in the study as well as for countries excluded based on low data quality is available on request.

${ }^{15}$ Arthur Okun was a member of President Kennedy's Council of Economic Advisers and was asked to investigate the gains of real GNP associated with unemployment reduction. He found that a decrease of one percentage point of unemployment was correlated with an increase of 3 percent in real GNP. This short-run statistical association came to be known as Okun's Law (Tobin, 1987).

${ }^{16}$ Note that the stability of Okun's Law has been called into question in particular when in the estimation of the relationship demand effects are separated out from supply effects (Blanchard and Quah, 1989). Labor hoarding in the short run is further influenced by many factors that depend on the state of the economy at the time of the output change, which have seriously called into question the prevalence of Okun's Law. In particular, the existence of short run adjustment costs for other inputs such as capital stock are likely to offset any bias of the Verdoorn coefficient due to Okun's Law (Jefferson, 1988). 


\footnotetext{
${ }^{17}$ Here a note of caution is offered regarding potential measurement error-a problem that may be more prone in developing country data. A potential measurement error will bias results toward zero in the two-variable case. ${ }^{18}$ Locfit is a software package designed for usage in S-PLUS, making extensive use of the data management and graphical facilities. It performs local regression, likelihood and related smoothing procedures. For an introduction, see e.g. Loader (1997, 1999), Krause and Olson (1997), and Venables and Ripley (1997).

${ }^{19}$ The visual inspection of the residual plots for the nine sectors under investigation revealed that the results were not very sensitive to the choice of the bandwidth.

${ }^{20}$ Note that the difference between the 45 -degree line and the smooth curve is equal to productivity growth in the sector. In other words, the wider the gap between the 45-degree line and the sector's local regression line, the higher is the rate of growth of productivity in the sector (see also figure 1 for the graphical representation of the productivity-growth relationship).
} 
Bibliography

Amsden, A. H. and van der Hoeven, R. 1996. Manufacturing output, wages, and restructuring in the 1980s: labour's loss until the century's end, Journal of Development Studies, vol. 32, no. 4, pp. 506-30

Arrow, K. J. 1962. The economic implications of learning by doing, Review of Economic Studies, vol.14, pp.155-73

Bairam, E. I. 1987. The Verdoorn Law, returns to scale and industrial growth: a review of the literature, Australian Economic Papers, vol. 26, no. 48, pp. 20-42

Bernard, A. B. and Jones, C. 1996. Productivity across industries and countries: time series theory and evidence, Review of Economics and Statistics, vol. 87, no. 1, pp. 135-46

Blanchard, O. J. and Quah, D. T. 1989. The dynamic effects of aggregate demand and supply disturbances, American Economic Review, vol. 79, pp. 655-73

Chenery, H., Robinson, S. and Syrquin, M. 1986. Industrialization and Growth-A Comparative Study, New York, Oxford University Press

Cripps, T. F. and Tarling, R. J. 1973. Growth in Advanced Capitalist Economies, 1950-70, Cambridge, CUP

Destefanis, S. 1999. The Verdoorn Law: Some evidence from non-parametric frontier analysis, mimeo, University of Salerno, Italy

Durlauf, S. N. and Quah, D. T. 1999. The new empirics of economic growth, in Taylor, J. and Woodford, M. (eds.) Handbook of Macroeconomics, Netherlands, Elsevier Science Publishers

Gomulka, S. 1983. Industrialization and the rate of growth: Eastern Europe 1955-75, Journal of Post Keynesian Economics, vol. 5, no. 3, pp. 388-96

Jacoby, W. G. 1997. Statistical Graphics for Univariate and Bivariate Data, London, Sage Publications

Jefferson, G. H. 1988. The aggregate production function and productivity growth: Verdoorn's Law revisited, Oxford Economic Papers, vol. 40, no. 4, pp. 671-91

Kaldor, N. 1966. Causes of the Slow Rate of Economic Growth in the United Kingdom, Cambridge, CUP

Kaldor, N. 1968. Productivity and growth in manufacturing industry: a reply, Economica, vol. 35 (November), pp. $385-91$

Kaldor, N. 1975. Economic growth and the Verdoorn Law-a comment on Mr. Rowthorn's article, Economic Journal, vol. 85 (December), pp. 891-96

Krause, A. and Olson, M. 1997. The Basics of S and S-PLUS, New York, Springer

Loader, C. R. 1997. Locfit: an introduction, Statistical Computing and Graphics Newsletter, April

Loader, C. R. 1999. Local Regression and Likelihood, New York, Springer

McCombie, J. S. L. 1983. Kaldor's laws in retrospect, Journal of Post Keynesian Economics, vol. 5, no. 3, pp. 414- 
McCombie, J. S. L. and de Ridder, J. P. 1984. The Verdoorn Law controversy: some new empirical evidence using the US State Data, Oxford Economic Papers, vol. 36, pp. 268-84

Michl, T. R. 1985. International comparisons of productivity growth: Verdoorn's Law revisited, Journal of Post Keynesian Economics, vol. 7, no. 4, pp. 474-92

Nelson, R. R. 1998. The agenda for growth theory: a different point of view, Cambridge Journal of Economics, vol. 22, no. 4, pp. 497-520

Okun, A. M. 1962. Potential GNP: Its measurement and significance, Proceedings of the Business and Economics Section, pp. 98-104, Washington, DC, American Statistical Association

Pieper, U. 2000. Deindustrialization and the social and economic sustainability nexus in developing countries: cross-country evidence on productivity and employment, Journal of Development Studies, vol. 36, no. 4 (April), pp. 66-99

Ros, J. 2000. Development Theory and the Economics of Growth, Ann Arbor, University of Michigan Press Rosenstein-Rodan, P. N. 1943. Problems of industrialization of Eastern and South-Eastern Europe, Economic Journal, vol. 53 (June), pp. 202-11

Rowthorn, R. E. 1975A. What remains of Kaldor's Law?, Economic Journal, vol. 85 (March), pp. 10-9

Rowthorn, R. E. 1975B. A reply to Lord Kaldor's comment, Economic Journal, vol. 85 (December), pp. 897-901

Rowthorn, R. E. 1979. A note on Verdoorn's Law, Economic Journal, vol. 89 (March), pp. 131-3

Temple, J. 1999. The new growth evidence, Journal of Economic Literature, vol. 37, no. 1 (March), pp. 112-56

Thirlwall, A. P. 1983. A plain man's guide to Kaldor's growth laws, Journal of Post Keynesian Economics, vol. 5, no. 3 , pp. $345-58$

Thirlwall, A. P. 1987. Nicholas Kaldor, New York, New York University Press

Thirlwall, A. P. and Dixon, R. 1975. A model of regional growth rate differences on Kaldorian lines, Oxford Economic Papers, vol. 27, no. 2 (July), pp. 201-14

Tobin, J. 1987. Okun, Arthur M., in Eatwell, J., Milgate M. and Newman P. (eds.) The New Palgrave: A Dictionary of Economics, London, Macmillan

Vaciago, G. 1975. Increasing returns and growth in advanced economies: A re-evaluation, Oxford Economic Papers, vol. 27, no. 2 (July), pp. 232-9

Venables, W. N. and Ripley, B. D. 1997. Modern Applied Statistics with S-PLUS, New York, Springer Verlag Verdoorn, P. J. 1949. Fattori che regolano lo sviluppo della produttivitá del lavoro. L'industria, vol. 1, pp. 3-10. English translation by Thirlwall, A. P. 1988, in Ironmonger, D. et al. (eds.), National Income and Economic Progress: Essays in Honour of Colin Clark, London, Macmillan

Verdoorn, P. J. 1980. Verdoorn's Law in retrospect: a comment, Economic Journal, vol. 90 (June), pp. 382-5 